\title{
Military Equipment Innovation in the Pahang Uprising
}

\author{
Amnah Saayah Ismail1, Burhanuddin Jalal, Nor Nazimi Mohd Mustaffa, Nur Surayya Mohd \\ Saudi
}

\begin{abstract}
The Pahang uprising at the end of the 19th century $A D$ featured various military innovation that proved the greatness of the Pahang Malay community. Pahang Malay Fighters used the advantage of their knowledge of nature (the forest) in addition to modern military equipment. Hence, it is the intention of the researchers to examine and identify the military tools used during the Pahang uprising. This paper utilises the methodology of content analysis and literature review. Based on the examination, it was found that military tools such as 'sumpit' and tree roots were used in the Pahang uprising as well as modern weapons such as guns and explosives. All of these tools were fully utilised in the formulation of war strategy planned by the leader of the Pahang fighters in the uprising, Dato' Bahaman. This combination of war strategy and military innovation became the benchmark of the greatness of the Pahang Malay community in the late 19th century $A D$.
\end{abstract}

Keywords: Military Equipment, Pahang Fighters, Pahang Revolt Events, 19 AD

\section{INTRODUCTION}

$\mathrm{T}$ he 19th century AD saw Pahang as a rich state with plenty of natural resources and minerals. The wealth of Pahang was the dream of many parties including the British who are trying to expand their colonies at that time. The goal of the British was to colonise all the states of the Malay Peninsula and to put their advisers as representatives of the British administration. As the head of the Pahang state of administrators, the Sultan of Pahang was in a dilemma in the face of a crisis between the British and the people of Pahang.

However, in the end, with an extensive range of plotting and planning, the British managed to make Pahang state a colony in 1888 and placed J. P Rodger as the first British resident in Pahang. Hence, his was beginning of the opposition by the Pahang people which was led by Dato' Bahaman. The issue of payment of allowances was made a big

Revised Manuscript Received on September 22, 2019

* Correspondence Author

Amnah Saayah Ismail*, Department of Nationhood Leadership and Civilizarion, National Defence University of Malaysia, Kuala Lumpur, Malaysia. Email: amnah@upnm.edu.my

Burhanuddin Jalal, Name, d Department of Nationhood Leadership and Civilizarion, National Defence University of Malaysia, Kuala Lumpur, Malaysia. Email: burhanuddin@upnm.edu.my

Nor Nazimi Mohd Mustaffa, Department of Nationhood Leadership and Civilizarion, National Defence University of Malaysia, Kuala Lumpur, Malaysia. Email: nornazmi@upnm.edu.my

Nur Surayya Mohd Saudi, Academic Centre Development, National Defence University of Malaysia, Kuala Lumpur, Malaysia. Email: nursurayya@upnm.edu.my issue by the British. However, the fact was that the Pahang people did not like the foreigners interfering with the matters of their land. The people of Pahang rose to express their displeasure and anti-colonial spirit in a major event known as the Pahang uprising. The uprising took place in two series between 1891 and 1895. It featured various war strategies and military innovations of the Pahang fighters thinking and power. Hence, this paper sought to discover the kinds of military equipment used by the Pahang fighters in both series of the Pahang uprising events which proved that the Pahang fighters and the Malays at the time already possessed the ability to create and diversify their creativity including in the military field.

\section{METHODOLOGY}

This study employed the qualitative approach with emphasis on content analysis. This method was chosen since this study did not involve any statistical analysis or any other quantitative measurements. Content analysis was chosen as the research design in analysing the military equipment innovation in the Pahang Uprising. In conducting this study, the researchers need to browse through journals, books, articles, manuscripts, working papers, magazines, notes, documents, working papers and other written materials in order to extract information on the subject of study. Among the sources referenced are 'History of Pahang' by W. Linehan, The Pahang Uprising by Jang Aisjah Muttalib, several articles by Hugh Clifford and many others. The information obtained in this study has enabled the researchers to gain better understanding of the military equipment innovation in Pahang uprising.

\section{THE PAHANG UPRISING}

The Pahang uprising took place around 1891 to 1895 . The uprising was an event that unleashed the Pahang people's displeasure over the presence of the British colonisers in Pahang. This event was led by Dato' Bahaman who was supported by many Pahang fighters including Tok Gajah, Mat Kilau, Mat Lela and many others. The Pahang state administration at the time was under the rule of Sultan Ahmad. Sultan Ahmad was in a dilemma between his love for the Pahang people and his political relations with the British administration [5]. Among the factors that led to the occurrence of this uprising was due to the displeasure of the Pahang the appointment of British Officer J. P Rodger as the first British resident in Pahang in 1888. The appointment of this resident signified the shift of power from the Sultan to the British government [1]. In addition, the introduction of new systems that replaced the 
traditional rule under Sultan Ahmad such as the establishment of the court, the police force, the state council and the formation of new laws had increased the Pahang people's hatred towards the British colonialists. The appoint of the resident had resulted in the local authority losing control of their power where Sultan Ahmad was only in charge pertaining to matters of Malay customs and Islam only. British colonialist of Pahang had disturbed and undermined the traditional system of administration that had been practiced for so long in Pahang [2].

The peak of Pahang people's hatred towards the British colonisers was when Dato' Bahaman was deprived of his post as Pahang's leader. It was the first time that this had happened in the state of Pahang and this caused displeasure and unhappiness to grow and escalate among the people. Hence, the rebellion dreaded by the British finally happened. There were two series of Pahang revolts that took place during the years of 1891 to 1895 . The first Pahang uprising witnessed the spirit of struggle and extraordinary warfare among the Pahang fighters. It started in Lubuk Terua [7]. Various strategies were used by the fighters led by Dato' Bahaman to ensure victory for the Pahang forces. Similarly, the British who was led by Desborough responded by counter attackings the Pahang fighters. J. P Rodger was not in Pahang and was on duty as acting resident in Selangor at the time [2]. The British counter-attack resulted in the Pahang fighters retreating to Kelantan and later to Terengganu. The Pahang fighters were seen as being defeated by the withdrawal. However the truth was that the withdrawal gave the Pahang forces the opportunity to come up with a stronger and better war strategy and rally into a more powerful forces which the baritish forces did not anticipate.

The Pahang uprising did not cease with the withdrawal of Dato' Bahaman and his forces to Kelantan and Terengganu. The 2 years of silent period caused Pahang fighters made a preparation to prove their hatred against the British colonialists. There was a series of Pahang rebellions which witnessed the spiritual element coming into play in their their recent uprising. In Paloh there was a prominent scholar named, Tok Ku Paloh who played an important role in injecting religious elements into the fight of the Pahang fighters. Tok Ku Paloh reinforced the understanding of Islam among the Pahang fighters to ensure that the second series of the uprising take place successfully [4].The jihad slogan against the kuffar became a spark of encouragement to the Pahang fighters in addition to their weoponries which were engraved with the holy verses of the Quran. The fighters fought vigorously with the intention of expelling the British invaders from Pahang. The fort of Jeram Ampai becomes a wager. The British nonetheless retaliated by sending hundreds of policemen to fight against the Pahang fighters. The fighters were eventually forced to withdraw because they were helpless against the great attacks of British troops [7]. The Pahang uprising event ended with British control over the Jeram Ampai fortress. Nonetheless, it was a feeling of great pride and satisfaction for the Pahang fighters to be able to successfully demonstrate their hatred toward the British colonisers.

\section{MILITARY EQUIPMENT INNOVATION IN THE PAHANG UPRISING}

Military equipment refers to the tools or weaponries used during combat or warfare. The Pahang fighters used a variety of weaponries or war tools in their enemy. Similarly, they were also making various innovations to produce their own design of weapons and war tools. Guns and explosives were the main weapon used in the battle of the Pahang uprising. However, knowledge of the forest and nature was fully utilised and it had inspired the Pahang fighters to create their own tools or weapons. Dato' Bahaman and his forces knew that they would be killed if they did not use their minds and put in their utmost affort as their weapons were more primitive and their forces was very small [6].

The Straits Times dated December 31, 1891 reported that there were opinions in relation to the strengths that existed in Bahaman's forces. Some of the opinions noted that the number of Dato' Bahaman's forces amounted to a total of 4000 followers who were vulnerable to bullet and move themselves from one place to another at an incredibly fast pace. Nevertheless, more accurate opinion is that Dato' Bahaman only had 500 followers who were armed with various types of old weapons such as blow guns, swords and rifles as well as modern weapons such as breeach-loading sniders and blunder buses.

These military innovations demonstrate the greatness of the Pahang fighters in generating ideas and creativity in battle. Although these military innovations seems simple and ordinary in their creation, these tools were enough to help Pahang fighters in facing the war against the British forces. Among the war tools and weapon that helped to reinforce the strategy of the Pahang fighters discussed in this paper are guns, senapang kek and senapang kapak, sumpit, roots of the spike moss plant, ring-rope, parang and pelias.

\section{Guns}

Guns are one of the weapons used in the Pahang uprising. The Pahang fighters were seen preparing early to obtain firearms before the rebellion materialised. Noriah [6] writes that weapons and bullets were smuggled from Singapore by a Kelantan man named Awang Ngah who was merchant. This opinion is in line with the report by Syers, a British police officer in Pahang at the time, who reported based on his observation that the locals were keeping some firearms and ammunitions but he was uncertain of the number of ammunitions being kept there and that in his opinion the local people were planning or attempting to strike up a revolt against the British. Additionally, his queries to the locals in the upriver area as well as the dissatisfaction that was magnifying among the locals due to their displeasure with the new system introduced in Pahang by the British also led Syer's to anticipate an uprising [7].

In addition to the efficient preparation of the Pahang fighters by buying firearms, there were also those which were acquired through seizure after seizing control or taking over a place. There are records indicating as a result of 
situation where Dato' Bahaman's followers were blocked from getting food supplies led to them robbing and killing a few retailers in Temerloh and taking into their possession 40 Malay guns which were seized by the police in previous fight [6]. Similarly, after the raid on Kuala Tembeling police station on June 14, 1894 no less than 250 boxes of guns and other weapons were seized [2].

\section{Senapang Kek and Senapang Kapak}

Senapang Kek and Senapang Kapak are a kind of weapon that is the innovation of the Pahang fighters. These rifles were designed by the Pahang fighters. It is said that the use of this type of shotgun required the ammunition to be place in dry coir before being loaded. The coir and the bullet had to be thumped or hit several times and only then would it explode [6].

\section{Sumpit}

Sumpit is a manual weapons innovated by the Pahang fighters under Dato' Bahaman. Sumpit is a weapon created by the Pahang indigenous people who joined forces with Dato' Bahaman as part of his army and fighters. Sumpit is a long wooden blowpipe, from which poison-tipped or barbed darts are blown and were used primarily for hunting. There numerous occasions where the indigenous Pahang fighters used sumpit as a tool when a battle took place. Among them is the one where the pahang fighters rolled large builders and used the sumpit as a weopons to attack the British forces when the British forces were trawling for Dato' Bahaman and his men [2]. In one incident, Dato' Bahaman was able to meet Sultan Ahmad when he arrived in Temerloh despite the presence of J. P Rodger. Selampit who saw Rodger sitting with the Sultan in a boat had initially wanted to blowpipe him using the sumpit but was advice against carrying out the assassination by Bahaman so as to avoit hitting the Sultan [6]. Similarly, fighting events in Kampung Chat saw sumpit being used as weapons. At the time, the Pahang fighters were headed by Mat Kilau who was waiting for the Sikhs army on Bukit Berapit, at Kampung Chat. The Pahang fighters are assisted by the indigenous people who used sumpit as their weapon [7].

\section{Roots of the Spike Moss Plant}

Roots of the Spike Moss plant were used as an camouflage when Dato' Bahaman was in the forest. He used this strategy especially when he was pursued by Sikh constables who were tasked to apprehend him in Pasir Dir. He also used roots of spike moss plant wound over the wound on his head and body to the practise of the aborigines. This startled the Sikh constables who fled and jumped into the river [2].

\section{Ring-rope}

Ring-rope is another military equipment innovation in the Pahang uprising. This is another strategy used by Dato' Bahaman against the British was where the ring-rope would be laid on the river bed in Lubuk Sanggarat. The ring-rope would be strung across the river and tied to two Merbau trees opposite each other on the river banks. Making use of what nature presents, Dato' Bahaman and his men would then yank the rope as boats carrying British troops passed by. The boats would overturn and the British troops would be drowned by the strong current. At other times, they will let the British troops passed by and only on their return trip, Dato' Bahaman and his men will employ this same strategy. British soldiers who fell into the river would then be blow-piped by Dato' Bahaman's men [2].

\section{Parang and Pelias}

Parang and Pelias are also weaponry or war tools used in the Pahang uprising particularly in the second series of the rebellions. The fighters realised that the strength of a strong Islamic power would enable them to achieve their goals. They were also given pelias (azimat or amulets) and parang (long knives) with surahs of the Qur'an carved on these weopon by Tok Ku Paloh. The preparations based in Paloh were accompanied by prayers and blessings Tok Ku Paloh who would hand over several weapons of hikmat written with the verses of the Quran [6][1].

\section{CONCLUSION}

In conclusion, the Pahang uprising was a result the Pahang people's hatred and dissatisfaction with the British invaders. It witnessed two series of great rebellions that demonstrated the greatness of collective military strategy and innovation developed by the Pahang fighters who were headed by Dato' Bahaman. Although sumpit, parang, ring-rope, senapang kek and senapang kapak and roots of spikemoss plant are considered primitive tools, they are proof of the greatness of the Pahang Malays in innovating to produce their own military tools and weaponries. It also demonstrates the forces of thought and creativity of the Pahang fighters which reached the height of civilisation in producing military tool production that were deployed in the two series of Pahang rebellions.

\section{REFERENCES}

[1] Aruna Gopinath. 1993. Sejarah Politik Pahang 1880-1935. Selangor:Dewan Bahasa dan Pustaka.

[2] Linehan, W. 1936. History of Pahang. JMBRAS. Vol XIV part II:44-199.

[3] Ismail, A. S., Mujani, W. K., Jalal, B., \& Zainal Shah, N. (2019). Analysis of Dato' Bahaman's battle strategies in the Pahang uprising 1891-1895. International Journal of Civil Engineering and Technology, 10(1)

[4]Ismail, A. S., Shah, N. Z., Mujani, W. K., \& MdRessad, I. S. (2014). Scholars' Jihad Ta'limi in pahang during the $19^{\text {th }}$ Century. Middle East Journal of Scientific Research, 20(12).https://doi.org/10.5829/idosi.mejsr.2014.20.12.21111

[5] Mujani, W. K., Ismail, A. S., Resad, I. S. A. M., \& Shah, N. Z. (2014). Sultan Ahmad: The dilemma between the local rebels and British colonialists in Pahang at the end of the $19^{\text {th }}$ century. Asian Social Science, 10(3). https://doi.org/10.5539/ass.v10n3p205

[6] Noriah Sulung. 1996. Dato' Bahaman: Orang Kaya Setia Perkasa Pahlawan Semantan in Norazit Selat Ed 1996). Dlm Pahang Dahulu dan Sekarang. pp: 34-56. Kuala Lumpur: Persatuan Muzium Malaysia.

[7] Morrah, Patrick. 1963. The History of The Malayan Police. Journal of The Malayan Branch of Royal Asiatic Society. Vol 36 Part 2 No 202: 76-88. 


\section{AUTHORS PROFILE}

Amnah Saayah Ismail currently works as a Senior Lecturer at the Department of Nationhood, Leadership and Civilization, Faculty of Defence and Management Studies, National Defence University of Malaysia (NDUM). Her Ph. D in Arabic Studies and Islamic Civilization

from National University of Malaysia. Amnah does research in History of Civilization, Islamic History of Tanah Melayu before 19 Century, Islamic Scholars of Nusantara, Community Services and leadership. Her current project is Social Enterprise at Urban Community with Stroke Survivors.

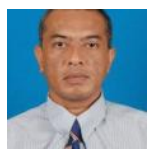

Burhanuddin Jalal is a Senior Lecturer at the Departmen of Nationhood, Leadership and Civilization, Faculty of Defence and Management Studies, National Defence University of Malaysia (NDUM). He joined NDUM in 2014 and has served NDUM until today. Previously he was Army officer with the rank of Colonel at Malaysian Army Headquarters of the Malaysian Armed Forces. His PhD is in Islamic Studies from the National University of Malaysia. His research interest is in the field of Islamic leadership, Islamic organization management and Islamic preaching $\left(d a^{\prime} w a h\right)$. He has received a number of a research grant in the area of Islamic studies in the area of Islamic practices and Muslim behaviour. He has been involved in consultation work and community service. Burhanuddin Jalal has published several academic writing related to his field in the journal. His latest book which title 'Dakwah Askari di Malaysia' (2018), was published by Islamic Sciences University of Malaysia (USIM), chapters in the book (12) and conference papers (27). He also actively wrote on currents issues in Malaysian daily Newspaper especially Berita Harian and Utusan Malaysia. His current research project is on wakaf and endowment in Malaysia.

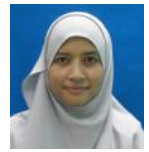

Nor Nazimi Mohd Mustaffa currently works as Senior Lecturer at National Defence University of Malaysia. Her $\mathrm{Ph}$. D in Islamic Civilization from National University of Malaysia, Master. of Islamic Civilization and Bachelor of Islamic Studies also from National University of Malaysia. Nor Nazimi does research in Islamic Civilization, Psychology of Religion, Philosophy and Religious Behavior Development.

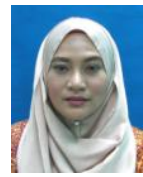

Nur Surayya Mohd Saudi was a Financial Analyst in the Top 5 Banks in Malaysia and possess a vast experience in Banking and Finance. Surayya currently works as Lecturer and holding a position as Deputy Director at Centre of Academic at National Defence University of Malaysia. Her PhD is in Financial Economics from Universiti Malaysia Sabah. Nur Surayya research areas are in Financial Economics, Defence Economics, International Economics, Human Resource in Economics, Leaderships study and Islamic Quality Management. She is the module convener in economics for Malaysia Resilience Defence College, Malaysia. Her current project is to study the effect of military expenditure in ASEAN 10 economies. Surayya is actively involved in Corporate Social Responsibility nationally and Internationally. She also an active member for Malaysia Economic Association (MEA). 